\title{
ANALISIS PERBEDAAN KINERJA PETANI KAKAO MITRA DAN NON MITRA DENGAN PT OLAM INDONESIA DI KABUPATEN PESAWARAN
}

\author{
(Analysis of Performance Differences between Partners and Non Partners of Cocoa Farmers with PT Olam \\ Indonesia in Pesawaran District)
}

Rahmi Eka Putri, Zainal Abidin, Eka Kasymir

Jurusan Agribisnis, Fakultas Pertanian, Universitas Lampung, J1. Prof. Dr. Soemantri Brodjonegoro No. 1 Bandar Lampung 35145, Telp 082280244687, email: rahmi_eka12@yahoo.co.id

\begin{abstract}
This research intended to differentiate the productivity and cocoa farming revenue of partner farmers and non-partner farmers in in Sungai Langka and Wiyono villages of Pesawaran district. The research was conducted by survey method in which data was collected in January 2017 and analyzed by descriptive quantitative method. The locations of this research were chosen by gradual sampling. This research envolving all 54 cocoa farmers as respondents in that villages. The data was analyzed by analysis tools of difference and farming revenue. The results showed that based on the analysis of difference there was no difference in cocoa productivity between partner farmers and non-partner farmers; whereas, there was difference in cocoa farming revenue between partner farmers and non-partner farmers
\end{abstract}

Key words: cocoa, farmers, non-partner, partner

\section{PENDAHULUAN}

Kakao (Theobrema cacao L.) merupakan salah satu komoditas perkebunan yang peranannya cukup penting bagi perekonomian nasional, khususnya sebagai penyedia lapangan kerja, sumber pendapatan dan devisa negara. Disamping itu kakao juga berperan dalam mendorong pengembangan wilayah dan pengembangan agroindustri. Pada tahun 2002, perkebunan kakao telah menyediakan lapangan kerja dan sumber pendapatan bagi sekitar 900 ribu kepala keluarga petani yang sebagian besar berada di Kawasan Timur Indonesia (KTI) serta memberikan sumbangan devisa terbesar ke tiga sub sektor perkebunan setelah karet dan kelapa sawit dengan nilai sebesar US \$ 701 juta (Pusdatin 2016). Berdasarkan data dari BPS (2016), jumlah produksi kakao di Indonesia pada 2012 s/d 2015 yaitu 740,51 ribu ton, 720,86 ribu ton, 728,40 ribu ton, dan 661,2 ribu ton.

Kabupaten Pesawaran merupakan salah satu Kabupaten yang ada di Provinsi Lampung yang memproduksi kakao. Kabupaten Pesawaran memiliki konstribusi dalam menyumbang jumlah produksi kakao di Lampung. Berdasarkan data yang dihimpun oleh BPS Kabupaten Pesawaran tahun 2016, produksi kakao mencapai 9.364,40 ton.
Kecamatan Gedong Tataan masuk kedalam tiga besar kecamatan yang memproduksi kakao di Kabupaten Pesawaran. Salah satu desa di Kecamatan Gedong Tataan yaitu Desa Sungai Langka. Desa Sungai Langka menempati urutan pertama yang memproduksi kakao terbesar di Kecamatan Gedong Tataan yaitu sebesar 925 ton dengan produktivitas sebesar 9,74 kuintal/hektar (BPS Kabupaten Pesawaran 2016). Hal tersebut dikarenakan luas areal perkebunan kakao di Desa Sungai Langka lebih luas dibanding dengan daerah lain.

Petani kakao di daerah ini pun masih didominasi oleh perkebunan rakyat skala kecil. Teknik budidaya kakao pun masih belum optimal dikarenakan petani kakao yang masih menggunakan teknik budidaya yang diajarkan secara turun temurun. Selain itu, pupuk yang terjangkau, dan bahan tanam yang berkualitas menjadi permasalahan bagi perkebunan rakyat. Sebagai akibatnya kualitas biji kakao yang dihasilkan rendah. Oleh karenanya untuk mengatasi permasalahn tersebut perlu adanya kemitraan antara petani kakao dengan pihak lain untuk membantu peningkatan kualitas biji kakao.

Salah satu perusahaan yang melakukan kemitraan adalah PT Olam Indonesia di Bandar Lampung. Perusahaan PT Olam Indonesia merupakan salah satu perusahaan yang bergerak di sektor agribisnis. Salah satu produk yang dijual adalah biji kakao. 


\section{JIIA, VOLUME 6, No. 1, FEBRUARI 2018}

Biji kakao tersebut dijual perusahaan ke perusahaan yang mengolah biji kakao menjadi makanan. Oleh sebab itu, untuk memenuhi pasokan biji kakao yang berkualitas tinggi dan adanya keberlanjutan tersedianya produk, PT Olam Indonesia melakukan kerjasama kemitraan dengan petani kakao. Kegiatan kemitraan ini bukan hanya untuk memenuhi pasokan biji kakao saja, namun merupakan salah satu tanggung jawab sosial dari PT Olam Indonesia.

Adanya kemitraan diharapkan dapat menciptakan transfer pengetahuan, modal, dan teknologi dari PT Olam Indonesia ke petani kakao, sehingga produktivitas dan pendapatan usahatani kakao meningkat. Serta PT Olam Indonesia akan mendapatkan pasokan bahan baku berkelanjutan sesuai dengan kualitas. Berdasarkan penjelasan diatas maka, tujuan dari penelitian ini adalah untuk (1) mengetahui perbedaan produktivitas kakao petani mitra dengan non mitra, dan (2) mengetahui perbedaan pendapatan ushatani petani mitra dengan non mitra.

\section{METODE PENELITIAN}

Penelitian dilakukan di Desa Sungai Langka dan Wiyono, Kecamatan Gedong Tataan, Kabupaten Pesawaran. Lokasi penelitian ditentukan dengan menggunakan sampling bertahap, dimana ditentukan dahulu dimulai dari Kabupaten, Kecamatan, dan Desa. Kabupaten Pesawaran dipilih dengan pertimbangan bahwa di daerah tersebut menempati posisi kedua terbesar di Provinsi Lampung yaitu mencapai 9.364 ton/ha (BPS Provinsi Lampung 2016). Kecamatan Gedong Tataan dipilih dikarenakan kecamatan ini memiliki produksi terbesar ketiga di Kabupaten Pesawaran, produksi kakao mencapai 1.506,55 ton/ha (BPS Kabupaten Pesawaran 2015). Selain itu Kecamatan Gedong Tataan memiliki daerah yang terdapat pembinaan kakao dengan PT Olam Indonesia.

Desa Sungai Langka merupakan desa yang memiliki produksi kakao terbesar di Kecamatan Gedong Tataan, sedangkan Desa Wiyono menempati urutan ketiga. Berdasarkan BPS Kabupaten Pesawaran (2016), produksi kakao di Desa Sungai Langka mencapai 925 ton/ha dan Desa Wiyono memiliki produksi sebesar 59,90 ton/ha. Selain itu lokasi dipilih secara sengaja (purposive) dengan pertimbangan bahwa Desa Sungai Langka merupakan desa yang melakukan kemitraan antara PT Olam Indonesia, sehingga diharapkan dapat mewakili seluruh populasi petani mitra kakao yang ada. Sedangkan Desa Wiyono di pilih sebagai petani pembanding bagi petani non mitra karena adanya kelompok tani yang tidak ikut bermitra dengan PT Olam Indonesia dan masih aktifnya kelompok tani tersebut.

Pengambilan sampel dilakukan dengan metode sensus. Sampel yang digunakan yaitu anggota kelompok tani yang masih aktif pada tahun 2016. Kelompok tani mitra berjumlah dua dengan total anggota kelompok tani adalah 30, sedangkan responden petani non mitra hanya ada satu kelompok tani dengan jumlah anggota kelompok tani 24 orang. Jadi, total responden pada penelitian ini adalah 54 orang.

Data yang digunakan pada penelitian ini yaitu data primer dan data sekunder. Data primer didapat dari wawancara langsung dengan petani dengan menggunakan kuisioner yang telah dibuat. Data sekunder didapat dari Data sekunder diperoleh dari study literatur dan dari lembaga - lembaga / instansi terkait seperti BPS Provinsi Lampung, BPS Kabupaten Pesawaran, Balai Penyuluhan Pertanian, Perikanan dan Kehutanan (BP3K) Kecamatan Gedong Tataan, PT Olam Indonesia, Gabungan Kelompok Tani Manunggal Jaya di Desa Sungai Langka dan Kelompok Tani Sinar Harapan di Desa Wiyono.

Metode analisis yang digunakan adalah metode analisis deskriptif kuantitatif. Kemudian untuk mengetahui perbedaan produktivitas dan pendapatan usahatani kakao petani mitra dengan petani non mitra menggunakan alat analisis uji beda rata-rata. Hal tersebut sama dengan alat analisis penelitian Medika (2016). Menurut Lungan (2006), uji beda menggunakan rumus sebagai berikut:

$$
\mathrm{t}=\frac{\left(\overline{\mathrm{X}_{1}}-\overline{\mathrm{X}_{2}}\right)-\mathrm{d}_{0}}{\sqrt{\frac{\mathrm{SD}_{1}^{2}}{\mathrm{n}_{1}}+\frac{\mathrm{SD}_{2}^{2}}{\mathrm{n}_{2}}}}
$$

$$
\begin{aligned}
\text { Keterangan: } & \\
\mathrm{X}_{1}= & \text { Rata-rata produksi atau pendapatan } \\
& \text { usahatani kakao petani mitra } \\
\mathrm{X}_{2}= & \text { Rata-rata produksi atau pendapatan } \\
& \text { usahatani kakao petani non mitra } \\
\mathrm{SD}_{1}= & \text { Simpangan baku petani mitra } \\
\mathrm{SD}_{2}= & \text { Simpangan baku petani mitra } \\
\mathrm{n}_{1}= & \text { Jumlah sampel petani mitra } \\
\mathrm{n}_{2}= & \text { Jumlah sampel petani non mitra } \\
\mathrm{d}_{0}= & \text { Konstanta }
\end{aligned}
$$


Penelitian ini juga menggunakan alat analisis pendapatan usahatani, dimana digunakan untuk mengetahui pendapatan usahatani kakao petani mitra dan non mitra, sama dengan penelitian Gusti (2013) yang menggunakan perhitungan pendapatan usahatani kakao. Pendapatan ushatani yang dihitung yaitu selisih penerimaan usahatani kakao dengan biaya usahatani kakao. Biaya usahatani yang digunakan dalam perhitungan pendapatan yaitu biaya tunai yang dikeluarkan petani. Hal tersebut dikarenakan pendapatan usahatani yang dihitung yaitu pendapatan usahatani pada tahun 2016. Menurut Suratiyah (2009), rumus pendapatan usahatani yaitu:

$\mathrm{Y}=\mathrm{TR}-\mathrm{TC}$

$\mathrm{TR}=\mathrm{P} . \mathrm{Q}$

$\mathrm{TC}=\mathrm{TFC}+\mathrm{TVC}$

Keterangan:

$\mathrm{Y} \quad=$ Pendapatan usahatani kakao $(\mathrm{Rp})$

$\mathrm{TR}=$ Total penerimaan $(\mathrm{Rp})$

$\mathrm{TC}=$ Total biaya $(\mathrm{Rp})$

$\mathrm{P} \quad=$ Harga $(\mathrm{Rp})$

$\mathrm{Q}=$ Jumlah produksi $(\mathrm{Kg})$

TFC = Total biaya tetap (Rp)

$\mathrm{TVC}=$ Total biaya variabel $(\mathrm{Rp})$

\section{HASIL DAN PEMBAHASAN}

\section{Karakteristik Responden}

Responden penelitian untuk petani mitra rata-rata usia $28-42$ tahun $(53,33 \%)$, sedangkan petani non mitra rata-rata $45-56$ tahun $(66,67 \%)$. Rata-rata responden penelitian memiliki jenjang pendidikan terakhir adalah sekolah dasar baik petani mitra $(50,42 \%)$ dan non mitra $(54,17 \%)$. Petani mitra dan petani non mitra memiliki jumlah tanggungan rata-rata 3-4 orang, dimana petani non mitra memiliki persentase lebih tinggi $(70,83 \%)$ dibanding petani mitra $(66,67 \%)$. Petani mitra rata-rata memiliki pengalaman berusahatani $17-28$ $(46,67 \%)$, sedangkan petani non mitra 5-16 tahun $(45,83 \%)$.

Selain berusahatani kakao, petani responden memiliki pekerjaan sampingan dalam memenuhi kebutuhan dalam rumah tangga baik dalam off farm maupun non farm. Pekerjaan sampingan petani responden petani mitra lebih banyak didominasi off farm $(80,00 \%)$, sedangkan petani non mitra lebih banyak non farm $(76,92 \%)$. Ratarata persentase luas lahan yang dimiliki petani kakao berkisar 0,25-1,17 hektar (80\%). Hasil penelitian menunjukan bahwa $100 \%$ petani kakao baik di petani mitra dan petani non mitra memiliki sendiri lahan kakao yang diusahakan. Karakterisktik responden dapat dilihat pada Tabel 1.

\section{Pembinaan PT Olam Indonesia Kepada Petani Kakao di Desa Sungai Langka}

Perusahaan PT Olam Indonesia melakukan pembinaan di Kabupaten Pesawaran, Pringsewu, Lampung Selatan, dan Tanggamus. Kabupaten Pesawaran merupakan daerah yang lebih lama mendapat binaan dari PT Olam Indonesia. Terdapat dua kecamatan di Kabupaten Pesawaran yang dibina PT Olam Indonesia yaitu Kecamatan Gedong Tataan dan Way lima. Kelompok tani di Kecamatan Gedong Tataan lebih dahulu melakukan pembinaan dengan PT Olam Indonesia dibanding Kecamatan Way Lima.

Program yang diberikan pihak perusahaan yaitu cocoalife yaitu program budidaya kakao dimulai dari pembibitan hingga pasca panen. Pembinaan budidaya kakao yang diberikan yaitu pemeliharaan,pemmbuatan pupuk kompos, panen, pasca panen, dan peremajaan. Pemeliharaan kakao yang dimaksud yaitu seperti harus dilakukannya panen sering untuk memutus mata rantai busuk buah. Selain itu adanya pemangkasan berat dan ringan. Pembuatan pupuk kompos yang diajarkan perusahaan yaitu dengan memanfaatkan kulit-kulit sisa panen. Kegiatan panen juga dilakukan pembinaan dikarenakan cara panen petani yang salah selama ini. Cara panen yang dianjurkan yaitu jangan sampai merusak bantalan kakao, karena akan berpengaruh pada hasil produksi yang selanjutnya.

Tabel 1. Karakteristik Responden Petani Mitra dan Non Mitra

\begin{tabular}{clcc}
\hline No & \multicolumn{1}{c}{ Keterangan } & $\begin{array}{c}\text { Petani Mitra } \\
(\%)\end{array}$ & $\begin{array}{c}\text { Petani Non Mitra } \\
(\%)\end{array}$ \\
\hline 1. & Usia petani & 93,33 & 91,67 \\
2. & $\begin{array}{l}\text { Pendidikan } \\
\text { terakhir }\end{array}$ & 50,42 & 54,17 \\
3. & $\begin{array}{l}\text { Jumlah } \\
\text { Tanggungan }\end{array}$ & 66,67 & 70,83 \\
4. & $\begin{array}{l}\text { Pengalaman } \\
\text { berusahatani }\end{array}$ & 46,67 & 45,83 \\
kakao & & \\
5. & $\begin{array}{l}\text { Pekerjaan } \\
\text { sampingan }\end{array}$ & 80,00 & 76,92 \\
6. & Luas lahan & 76,67 & 83,33 \\
\hline
\end{tabular}


Kegiatan pasca panen pihak perusahaan menganjurkan untuk melakukan penjemuran lebih dari sehari yaitu sekitar 5-6 hari untuk mendapatkan hasil kakao yang memiliki kadar air maksimal 6-7\%. Pihak perusahaan juga memberikan pelajaran mengenai peremajaan. Hal ini didasarkan karena usia kakao yang sudah tidak lagi produktif. Oleh karena itu, dianjurkan petani melakukan peremajaan dengan teknik sambung samping dan pucuk.

Selain memberikan program kemitraan mengenai budidaya kakao, pihak perusahaan juga menampung hasil panen. Perusahaan menerima hasil panen petani dengan syarat kadar air maksimal 6-7\%. Beberapa petani mitra sudah ada yang melakukan penjualan secara kering ke PT Olam Indonesia. Petani mitra yang menjual biji kakao kering akan mendapat fee sebesar Rp400/kg.

\section{Alokasi Sarana Produksi Kakao}

Rata-rata penggunaan pupuk petani mitra mencapai $755,955 \mathrm{~kg} / \mathrm{ha}$, sedangkan petani non mitra sebesar $464,75 \mathrm{~kg} / \mathrm{ha}$. Biaya rata-rata pemupukan yang dikeluarkan petani mitra yaitu Rp422.702,78, sedangkan petani non mitra yaitu Rp395.920,13. Biaya pemupukan petani mitra lebih tinggi dibanding petani non mitra. Perbedaan tersebut dikarenakan adanya perbedaan rata-rata penggunaan pupuk yang lebih besar petani mitra.

Penggunaan pestisida petani non mitra lebih tinggi dibandingkan petani mitra. Rata-rata penggunaan pestisida petani non mitra yaitu 0,71 liter/ha, sedangkan petani mitra sebesar 0,46 liter/ha. Jika dilihat dari segi biaya pestisida yang dikeluarkan, petani non mitra juga lebih tinggi biaya yang dikeluarkan dibandikan petani mitra. Biaya pestisida petani non mitra mencapai Rp33.961,42/tahun, sedangkan petani mitra Rp16.709,04/tahun.

Rata-rata penggunaan kapur petani mitra sebesar $82,50 \mathrm{~kg} / \mathrm{ha}$, sedangkan petani non mitra mencapai $52,08 \mathrm{~kg} / \mathrm{ha}$. Lebih tingginya penggunaan kapur petani mitra dikarenakan petani non mitra mengalokasikan kapur ke areal sawah miliknya. Jika dilihat dari segi biaya pengkapuran, rata-rata biaya pengapuran petani mitra lebih tinggi. Ratarata biaya kapur petani mitra yaitu Rp51.666,67/tahun, sedangkan petani non mitra yaitu Rp28.541,67/tahun.
Tenaga kerja yang banyak digunakan petani adalah tenaga kerja dalam keluarga baik untuk petani mitra dan petani non mitra. Hal tersebut dikarenakan luas lahan petani yang relatif sempit sehingga kegiatan usahatani hanya dilakukan oleh TKDK. Rata-rata penggunaan TKDK petani mitra yaitu 77,12 HOK/tahun, sedangkan petani non mitra sebesar 94,98 HOK/tahun. Rata-rata penggunaan TKLK petani mitra yaitu 13,54 HOK/tahun dan petani non mitra menggunakan 4,66 HOK/tahun.

\section{Perbedaan Produktivitas dan Pendapatan Usahatani Kakao Petani Mitra dan Non Mitra}

Rata-rata uji beda produktivitas kakao antara petani mitra PT Olam Indonesia dengan petani non mitra diperoleh nilai signifikan (2-tailed) 0,685 pada tingkat kepercayaan 95\%. Berdasarkan hasil tersebut, maka terima hipotesis $\mathrm{H}_{0}$, artinya bahwa tidak adanya perbedaan produktivitas antara petani mitra dengan petani non mitra. Sehingga dapat dikatakan bahwa adanya kemitraan yang terjalin tidak berdampak positif secara statistik terhadap produktivitas kakao. Hal tersebut dapat dilihat dari penggunaan input dan usia kakao.

Jika dilihat dari segi input yaitu pupuk, pestisida, dan kapur, penggunaan pupuk dan kapur secara signifikan terdapat perbedaan secara nyata penggunaan antara mitra dan non mitra, berbanding terbalik dengan penggunaan pestisida yang tidak berbeda secara nyata. Berdasarkan Tabel 2, menunjukan bahwa signifikan dari penggunaan pupuk dan kapur yaitu 0,008 dan 0,084 , sedangkan penggunaan pestisida yaitu 0,275 .

Meskipun penggunaan pupuk dan kapur yang digunakan petani mitra lebih tinggi, namun tidak mepengaruhi produktivitas kakao. Hal tersebut dikarenakan adanya aplikasi dari penggunaan pupuk dan kapur yang berbeda antara petani mitra satu dengan yang lainnya.

Selain itu, umur tanaman kakao petani mitra yang sudah tua. Rata-rata umur tanaman kakao mitra yaitu diats 20 tahun. Kondisi tersebut yang membuat tidak produktivnya lagi tanaman kakao, meskipun adanya penambahan pupuk dan kapur yang diberikan. Oleh sebab itu, untuk meningkatkan produktivitas kakao perlu adanya peremajaan kakao. 
Tabel 2. Hasil uji beda rata-rata produktivitas, pendapatan usahatani, input, total biaya tunai, dan penerimaan petani mitra dan non mitra

\begin{tabular}{lrrrrr}
\hline Variabel & F & Sig. & t & Df & Sig. (2-tailed) \\
\hline Produktivitas kakao & 0,189 & 0,665 & 0,805 & 52 & 0,685 \\
Pendapatan usahatani kakao & 2,997 & 0,089 & $-1,758$ & 52 & 0,029 \\
Pupuk & 17,053 & 0,000 & 2,764 & 52 & 0,008 \\
Kapur & 6,526 & 0,014 & 1,759 & 52 & 0,084 \\
Pestisida & 0.067 & 0,797 & $-1,102$ & 52 & 0,275 \\
Penerimaan & 0,000 & 0,993 & $-1,689$ & 52 & 0,097 \\
Total biaya tunai & 16,370 & 0,000 & 2,397 & 52 & 0,020 \\
\hline
\end{tabular}

Berdasarkan hasil rata-rata uji beda untuk pendapatan usahatani kakao antara petani mitra PT Olam Indonesia dengan petani non mitra yang dapat di lihat pada Tabel 2 didapat nilai signifikan (2-tailed) 0,008 pada tingkat kepercayaan $95 \%$. Oleh karena itu, maka hipotesis tolak $\mathrm{H}_{0}$ yang artinya adanya perbedaan pendapatan usahatani kakao antara mitra dengan petani non mitra. Hal tersebut menunjukkan bahwa kemitraan yang terjalin mampu memberikan dampak positif terhadap pendapatan ushatani kakao petani mitra.

Berdasarkan penelitian tersebut, berbeda dengan hasil penelitian Pratiwi (2014). Pendapatan tunai usahatani antara petani mitra dan non mitra tidak memiliki perbedaan secara signifikan, didapat nilai signifikan (2-tailed) 0,694. Sehingga dapat disimpulkan tidak adanya perbedaan secara nyata atau signifikan terhadap pendapatan tunai usahatani antara petani mitra dan petani non mitra. Namun, uji beda pada pendapatan total ushatani menunjukan hasil yang signifikan antara petani mitra dan non mitra. Pendapatan usahatani yang berbeda nyata dapat dijelaskan dari segi penerimaan dan total biaya tunai. Hasil uji beda rata-rata penerimaan di dapat bahwa t-hitung sebesar -1,689 dengan nilai signifikan (2-tailed) 0,097 , artinya bahwa terdapat perbedaan secara nyata penerimaan antara petani mitra dan non mitra. Hal ini dikarenakan produksi dan harga jual kakao antara petani mitra lebih tinggi. Kemudian dilihat dari segi biaya produksi, didapatkan hasil uji beda rata-rata biaya produksi juga berbeda nyata antara petani mitra dan non mitra, dimana $t$ statistic yang didapat nilai signifikan (2-tailed) yaitu 0,020 . Hal tersebut artinya adanya perbedaan secara nyata biaya produksi petani mitra dan non mitra. Adanya perbedaan secara nyata pendapatan petani mitra dan non mitra dikarenakan penerimaan dan biaya tunai produksi petani mitra yang lebih tinggijuga dapat dilihat dari harga jual biji kakao.

Rata-rata harga jual petani mitra lebih tinggi dikarenakan ada beberapa petani mitra yang menjual biji kakao dalam keadaan kering (kadar air 6-7\%), sedangkan petani non mitra seluruhnya manjual dalam keadaan setengah kering. Hal tersebut sesuai dengan penelitian Supriatna, dan Dradjat (2011), menjeaskan bahwa hasil penelitian yang dilakuakn bahwa adanya peningkatan harga jual petani setelah melakukan kemitraan, harga jual kopi meningkat sebesar $13,1 \%$ dari Rp8.550 menjadi Rp9.670

Hasil uji beda rata-rata dapat dilihat pada Tabel 2. Pada Tabel 2 dapat dilihat signifikan (2-tailed) dari uji beda produktivitas, pendapatan usahatani, input, total biaya tunai, dan penerimaan petani mitra dan non mitra. Adanya perbedaan pendapatan petani mitra yang lebih tinggi memberikan manfaat dalam ushatani kakao. Menurut Hafsah (1999), salah satu manfaat adanya kemitraan yaitu usaha kemitraan berarti suatu upaya pemberdayaan yang lemah (petani/usaha kecil).

Terdapat beberapa indikator yang menjadi pembeda antara petani mitra dan petani non mitra. Indikator-indikator tersebut disajikan pada Tabel 3. Indikator-indikator yang dijelaskan pada penelitian ini meliputi kegiatan organisasi kelompok tani, input yang digunakan, output yang dihasilkan, kegiatan budidaya kakao, pemasaran kakao, ada tidaknya peremajaan kakao, penerimaan kakao, dan pendapatan usahatani kakao. Budidaya kakao secara garis besar sudah sesuai dengan aturan yang ada, contohnya untuk pemangkasan. 
Tabel 3. Perbedaan petani mitra dan non mitra

\begin{tabular}{|c|c|c|c|}
\hline No & Indikator & Petani mitra & Petani non mitra \\
\hline 1. & Organisasi & Struktur & Kurang terstruktur \\
\hline \multirow[t]{5}{*}{2.} & Input: & & \\
\hline & a. Bibit & Lokal, MCC 01, MCC 02 & Lokal \\
\hline & b. Pupuk & 760,46 & 311,46 \\
\hline & c. Pestisida & 0,46 & 0,71 \\
\hline & d. Kapur & 82,5 & 52,085 \\
\hline \multirow[t]{10}{*}{3.} & Budidaya: & & \\
\hline & a. Pemupukan & 1-2 kali dalam setahun & 1 kali dalam setahun \\
\hline & b. Pengkapuran & 1 kali dalam setahun & 1 kali dalam setahun \\
\hline & c. Penyiangan & Rutin & Jarang \\
\hline & d. Pemangkasan & Rutin & Jarang \\
\hline & e. Pemberantasan HPT & Rutin & Jarang \\
\hline & f. Pemanenan & 7-15 hari & $7-15$ hari \\
\hline & g. Pasca panen: & & \\
\hline & - Pengupasan dan sortasi & Di kebun & Di rumah \\
\hline & - Penjemuran & 1-6 hari & 1 hari \\
\hline 4. & Pemasaran & PT Olam Indonesia dan Tengkulak & Tengkulak \\
\hline 5. & Peremajaan & Ada & Tidak ada \\
\hline 6. & Biaya produksi & $4.954 .735,11$ & $2.601 .159,72$ \\
\hline 7. & Produksi & $1.826,97$ & $1.339,25$ \\
\hline 8. & Produktivitas & $1.753,93$ & $1.826,43$ \\
\hline 9. & Penerimaan & $26.932 .684,00$ & $34.700 .527,78$ \\
\hline 10. & Pendapatan & $31.379 .010,00$ & $24.260 .430,00$ \\
\hline
\end{tabular}

Pemangkasan menurut Pusat Penelitian dan Pengembangan Kakao (2010) di bagi menjadi dua yaitu pemangkasan bentuk dan produksi. Hasil penelitian menunjukkan bahwa pemangkasan yang dilakukan petani kakao mitra adalah sebagian besar pemangkasan produksi dan ada beberapa yang keduanya, sedangkan petani non mitra seluruhnya melakukan pemangkasan produksi.

Berdasarkan penelitian juga diketahui bahwa, di satu sisi kemitraan yang dijalani tidak mempengaruhi secara nyata produktivitas kakao, namun adanya kemitraan menjamin pemasaran kakao. Terjaminnya pemasaran kakao bagi petani mitra, petani tidak lagi hanya dapat menjual biji kakao kepada tengkulak dalam keadaan basah, namun menjual dalam keadaan biji kakao kering ke PT Olam Indonesia. Sedangkan petani non mitra hanya dapat menjual biji kakao basah ke tengkulak dan dengan harga yang rendah. Hal tersebut dikarenakan bahwa petani non mitra yang tidak ada penampung hasil biji kakao selain tengkulak.

\section{KESIMPULAN}

Tidak terdapat perbedaan produktivitas kakao antara petani mitra PT Olam Indonesia dengan petani non mitra. Hal tersebut ditunjang juga oleh uji beda input yang tidak berbeda nyata pula antara petani mitra dan non mitra. Terdapat perbedaan pendapatan usahatani kakao antara petani mitra PT Olam Indonesia dengan petani non mitra. Hal tersebut dikarenakan adanya perbedaan harga jual biji kakao, dimana harga jual biji kakao petani mitra lebih tinggi dibandingkan petani non mitra.

\section{DAFTAR PUSTAKA}

BPS [Badan Pusat Statistik]. 2016. Produksi Tanaman Kakao Indonesia 2012-2015 (Ton). https://www.bps.go.id/index.php/publikasi/in dex?Publikasi\%5BtahunJudul\%5D=\&Publik asi\%5BkataKunci\%5D=kakao\&yt0=Tampilk an [ 5 Januari 2017].

BPS [Badan Pusat Statistik] Provinsi Lampung. 2016. Produksi Tanaman Kakao Menurut Provinsi 2012-2014 (Ton). http://lampung 
bps.id/website/pdf_publikasi/Provinsi-Lampu ng-Dalam-Angka-2016.pdf. [5 Januari 2017].

BPS [Badan Pusat Statistik] Kabupaten Pesawaran. 2015. Produksi, Produktivitas, dan Luas Areal Tanaman Kakao Di Kabupaten Pesawaran Berdasarkan Kecamatan. https://pesawarankab.bps.go.id/ website/pdf_publikasi/Kabupaten-Pesawaran -Dalam-Angka-2015.pdf [5 Januari 2017].

BPS [Badan Pusat Statistik] Kabupaten Pesawaran. 2016. Produksi, Produktivitas, dan Luas Areal Tanaman Kakao Di Kecamatan Gedong Tataaan. https://pesawa rankab.bps.go.id/website/pdf_publikasi/Kabu paten-Pesawaran-Dalam-Angka-2016.pdf [5 Januari 2017].

Hafsah MJ. 1999. Kemitraan Usaha. Pustaka Sinar Harapan. Jakarta.

Medika C. 2016. Dampak El Nino terhadap produksi dan pendapatan agroindustri berbasis singkong di Desa Karang Anyar Kecamatan Gedongtataan Kabupaten Pesawaran. JIIA. Vol. 4 (4): http:// jurnal.fp.unila.ac.id/index.php/JIA/article/vie w/1516/1370 [6 Juni 2017].

Gusti AI. 2013. Pendapatan rumah tangga petani kakao di Desa Pesawaran Indah Kecamatan Padang Cermin Kabupaten Pesawaran. JIIA. Vol.1[4]. http://jurnal.fp.unila.ac.id/index. php/JIA/article/view/701/643 [6 Juni 2017].

Lungan R. 2006. Analisis Statistika dan Hitung Peluang. Graha Ilmu. Yogyakarta.
Pratiwi T. 2014. Evaluasi Kemitraan Antara PT Pagottan dengan Petani Tebu di Kabupaten Madiun. Skripsi. Institut Pertanian Bogor. Bogor. repository.ipb.ac.id/handle/12345678 9/7022. [18 Desember 2016].

Puslitbang [Pusat Penelitian dan Pengembangan] Kakao. 2010. Budidaya dan Pasca Panen Kakao. Puslitbang. Bogor. http://perkebunan. litbang.pertanian.go.id/wpcontent/perkebuna n_budidaya_kakao.pdf [25 Juli 2017].

Pusdatin [Pusat Data dan Sistem Informasi Pertanian]. 2016. Outlook Komoditi Kakao. KementrianPertanian.Jakarta:http://epublikas i.setjen.pertanian.go.id/epublikasi//outlook//2 016/Perkebunan/OUTLOOK\%20KAKAO\% 202016/files//common/downloads/OUTLOO KKAKAO202016.pdf[12November 2016].

Supriatna A dan Dradjat B. 2011. Pola Kemitraan Dalam Peningkatan Efisiensi Pemasaran Kopi Rakyat. Balai Pengkajian dan Pengembangan Pertanian dan Lembaga Riset Perkebunan Nusantara. Malang. pse.litbang.pertanian.go.id/ind/pdffiles/Pros _ 2012_06B_MP_Ade.pdf [9 April 2017].

Suratiyah K. 2009. Ilmu Usahatani. Penebar Swadaya. Depok. 
Tabel 4. Analisis penerimaan, produksi, biaya input, dan pendapatan usahatani kakao antara petani mitra dan petani kakao (2016)

\begin{tabular}{|c|c|c|c|c|c|c|c|c|c|}
\hline \multirow{3}{*}{ No } & \multirow{3}{*}{ Uraian } & \multicolumn{4}{|c|}{ Petani Mitra } & \multicolumn{4}{|c|}{ Petani Non Mitra } \\
\hline & & \multirow[b]{2}{*}{ Satuan } & \multirow[b]{2}{*}{ Jumlah } & \multicolumn{2}{|c|}{ Per Hektar } & \multirow[b]{2}{*}{ Satuan } & \multirow[b]{2}{*}{ Jumlah } & \multicolumn{2}{|c|}{ Per Hektar } \\
\hline & & & & Harga (000) & Nilai (000) & & & Harga (000) & $\begin{array}{l}\text { Nilai } \\
(000) \\
\end{array}$ \\
\hline \multicolumn{10}{|c|}{1 Biaya Produksi } \\
\hline \multicolumn{10}{|c|}{ a. Biaya Tunai } \\
\hline \multicolumn{10}{|c|}{ (1) Biaya Variabel: } \\
\hline & Pupuk kandang & $\mathrm{kg}$ & 2345,00 & 0,02 & 2,666 & $\mathrm{~kg}$ & 1163,19 & 0,005 & 7,291 \\
\hline & NPK & $\mathrm{kg}$ & 325,44 & 2,68 & 894,47 & $\mathrm{~kg}$ & 340,28 & 2,4 & 851,11 \\
\hline & Urea & $\mathrm{kg}$ & 343,94 & 1,866 & 730,055 & $\mathrm{~kg}$ & 326,39 & 1,96 & 646,94 \\
\hline & TSP & $\mathrm{kg}$ & 9,44 & 1,133 & 63,611 & $\mathrm{~kg}$ & 29,17 & 0,337 & 78,333 \\
\hline & Dolomit & $\mathrm{kg}$ & 158,33 & 0,266 & 96,66 & $\mathrm{~kg}$ & 104,17 & 0,044 & 57,083 \\
\hline & Calcit & $\mathrm{kg}$ & 6,67 & 0,033 & 6,66 & $\mathrm{~kg}$ & 0,00 & 0,00 & 0,00 \\
\hline & Pesnat & ltr & 0,13 & 5,333 & 21,33 & Ltr & 0,00 & 0,00 & 0,00 \\
\hline & Desinol & ltr & 0,07 & 3,333 & 3,33 & ltr & 0,00 & 0,00 & 0,00 \\
\hline & Gandasil & $\mathrm{kg}$ & 0,14 & 12,666 & 10,5 & $\mathrm{~kg}$ & 1,33 & 3,625 & 70,166 \\
\hline & Biota & ltr & 3,56 & 7,503 & 100,04 & ltr & 0,42 & 2,708 & 27,083 \\
\hline & Round up & ltr & 0,09 & 6 & 5,666 & ltr & 0,02 & 2,5 & 1,25 \\
\hline & Sidolaris & ltr & 0,10 & 5,333 & 7,83 & ltr & 0,54 & 4,791 & 19,375 \\
\hline & Alika & ltr & 0,00 & 0,00 & 0,00 & ltr & 0,92 & 11,739 & 42,083 \\
\hline & Sidabas & $\operatorname{ltr}$ & 0,00 & 0,00 & 0,00 & $\operatorname{ltr}$ & 1,69 & 13,75 & 59,027 \\
\hline & Gramaxone & ltr & 0,03 & 1,666 & 1,666 & $\operatorname{ltr}$ & 1,43 & 27,708 & 86,666 \\
\hline & TKLK & $\mathrm{Rp}$ & & & $3.529,800$ & $\mathrm{Rp}$ & & & $2.6472,98$ \\
\hline \multicolumn{10}{|c|}{ (2) Biaya Tetap: } \\
\hline & Pajak & $\mathrm{Rp}$ & & & 8 & $\mathrm{Rp}$ & & & 59,833 \\
\hline & Iuran poktan & $\mathrm{Rp}$ & & & 10 & $\mathrm{Rp}$ & & & 10 \\
\hline & Iuran jalan ustan & $\mathrm{Rp}$ & & & 20 & $\mathrm{Rp}$ & & & 0,00 \\
\hline & Total Biaya Tunai & & & & $5.577,659$ & & & & $2.432,395$ \\
\hline \multicolumn{10}{|c|}{ b. Biaya diperhitungkan } \\
\hline \multicolumn{10}{|c|}{ (1) Biaya Variabel: } \\
\hline & Penyusutan & $\mathrm{Rp}$ & & & 341,252 & $\mathrm{Rp}$ & & & 130,5 \\
\hline & TKDK & $\mathrm{Rp}$ & & & $26.472,988$ & $\mathrm{Rp}$ & & & $17.034,925$ \\
\hline \multicolumn{10}{|c|}{ (2) Biaya Tetap: } \\
\hline & Sewa lahan & $\mathrm{Rp}$ & & & $1.339,655$ & $\mathrm{Rp}$ & & & $\begin{array}{r}1.333 .333,3 \\
3\end{array}$ \\
\hline & Total Biaya Diperhitungkar & & & & $28.109,241$ & & & & $\begin{array}{r}18.498 .759, \\
67\end{array}$ \\
\hline \multirow[t]{2}{*}{2} & Penerimaan & & & & & & & & \\
\hline & Produksi & $\mathrm{kg}$ & $2.345,20$ & $23.908,33$ & $36.956,67$ & $\mathrm{~kg}$ & $1.455,92$ & 19,583 & $26.692,833$ \\
\hline
\end{tabular}

